\title{
Effects of Different Levels of the Major Nutrients and Lime on Coffee Yield in Puerto Rico ${ }^{1}$
}

\author{
Saulo J. Rodriguez, R. Bosque Lugo, E. G. Boneta \\ García, and A. Morales Muñoz ${ }^{2}$
}

\section{INTRODUCTION}

Field trials to determine the best nutrient combination for high coffee yields have been conducted by the personnel of the Agricultural Experiment Station of the University of Puerto Rico during the past three decades. The trials were established in the most common soils of the Coffee Region. The first part of the work was reported by Gómez et al. $(7)^{3}$ in which they covered the results obtained in a Catalina clay at Lares. Later on, Rodriguez et al. (10) reported the results obtained in four experiments established in Catalina clay and Alonso clay at Maricao and Castañer, respectively.

This third report covers the results obtained in a Los Guineos clay at Jayuya in which nitrogen, phosphorus, and potassium were applied at different levels to the Puerto Rico and Columnaris coffee cultivars.

\section{REVIEW OF LITERATURE}

Fertilizer trials with coffee in Puerto Rico have given variable results. McClelland (8) working in an alluvial-fan soil reported a favorable response of coffee to applications of potash, if suitably accompanied by nitrogen. In fact, nitrogen was detrimental to yield if not enough potassium was applied to the coffee trees. Gómez et al. (7) reported a positive response to phosphorus application in a Catalina clay at Lares while Rodriguez, et al. (10) obtained a significant increase in yield from nitrogen application in a Catalina clay at Maricao with the Puerto Rico coffee, but not so with the Columnaris. In the Alonso clay no significant results were obtained. All previous trials were obtained from shaded coffee plantations. On the other hand, Abruña et al. (1) found a positive response of unshaded Bourbon coffee to applications of both nitrogen and potassium in both Alonso and Los Guineos clays. Lime application has not shown any beneficial effect as reported by Bonnet et al. (4); Abruña et al. (1); and Rodríguez et al. (10); either in shaded or unshaded coffee.

1 Contribution from the Adjuntas and the Gurabo Substations. The work was carried under Federal project H-20. The cooperation of Mr. Luis A. Becerra from Jayuya is acknowledged.

2 Associate Horticulturist, Gurabo Substation; Assistant Agronomist in Charge, Assistant Agronomist, and Research Assistant in Agronomy, Adjuntas Substation, Agricultural Experiment Station, Mayagïez Campus, University of Puerto Rico, respectively.

${ }^{3}$ Italic numbers in parentheses refer to Iiterature Cited, p. 203. 


\section{PROCEDURE}

The field trial was established at Jayuya in a Los Guineos clay of 40-percent slope and an original soil $\mathrm{pH}$ of 4.5 .

The experimental plot was cleared of weeds and bushes, leaving just the suitable degree of shade of mixed leguminous trees, mostly guavas (Inga vera, L.) and guamás (Inga laurina, L.). From there on, annual pruning was made to leave approximately 30 - to 50 -percent shade. The plantation was traced on the square at a distance of $8 \times 8$ feet for the Puerto

T.ınLe 1.-Mean annual yield of Puerlo Rico coffee in a Los Guineos clay al Jayuya as affected by levels of major nutrients

\begin{tabular}{|c|c|c|c|c|c|c|c|c|}
\hline \multicolumn{3}{|c|}{ Description of treatment ${ }^{3}$} & \multicolumn{6}{|c|}{ Mean yield of market coffee for 6 crops } \\
\hline$x$ & $\mathrm{P}_{2} \mathrm{O}_{3}$ & $\mathrm{~K}_{2} \mathrm{O}$ & First & Second & Third & Fourth & Fifth & Sixth \\
\hline Lb./acre & Lb./acre & Lb./acre & Cwt./acre & Cuw./acrc & Cout./acre & Ciot./acre & Cust./acre & Cwt./acre \\
\hline 0 & 300 & 300 & 5.36 & 11.99 & 14.79 & 10.22 & 12.87 & 10.98 \\
\hline 100 & 300 & 300 & 5.90 & 15.45 & 18.49 & 20.37 & 15.77 & 27.43 \\
\hline 200 & 300 & 300 & 6.25 & 13.91 & 21.55 & 17.15 & 18.24 & 27.95 \\
\hline 300 & $\mathbf{0}$ & 300 & 5.47 & 12.94 & 18.12 & 19.63 & 15.00 & 29.62 \\
\hline 300 & 100 & 300 & 5.87 & 13.03 & 20.29 & 15.51 & 18.59 & 25.35 \\
\hline 300 & 200 & 300 & 7.74 & 13.99 & 20.06 & 17.03 & 18.06 & 26.56 \\
\hline 300 & 300 & 0 & 5.26 & 5.68 & 12.15 & 11.40 & 11.52 & 18.82 \\
\hline 300 & 300 & 100 & 3.45 & 6.78 & 11.25 & 10.06 & 11.99 & 14.59 \\
\hline 300 & 300 & 200 & 5.96 & 10.90 & 16.16 & 19.31 & 13.52 & 28.67 \\
\hline 300 & 300 & 300 & 7.26 & 12.94 & 21.89 & 17.62 & 21.60 & 26.61 \\
\hline 0 & 0 & 0 & 2.85 & 7.40 & 10.20 & 9.39 & 9.93 & 12.63 \\
\hline 300 & 300 & 300 & 5.55 & 12.42 & 18.30 & 19.50 & 16.97 & 27.45 \\
\hline
\end{tabular}

${ }^{1}$ All treatments except the last 2 received a lime application to raise the soil $\mathrm{pH}$ to 6.5 .

Rico cultivar, while a planting distance of $12 \times 12$ feet was used for the Columnaris cultivar.

The trees were brought from the Coffee Substation nursery in an earthen ball. All trees were planted at the same depth that they were found in the nursery.

Soil samples were taken for $\mathrm{pH}$ and lime-requirement analyses. Limerequirement analysis showed a need of 9 tons per acre to raise the $\mathrm{pH}$ to 6.5 .

During the first year, all trees were fertilized with 2 ounces of a 9-10-5 fertilizer. From there on, the trees were fertilized according to the list of treatments shown in table 1. Lime was incorporated in three annual applications to the topsoil of the plots requiring it. The treatments were randomly distributed in a $3 \times 4$ triple rectangular lattice with six replications for the Puerto Rico cultivar and a partially balanced incomplete-block 
design with five replications for the Columnaris cultivar. Each experimental plot consisted of four trees.

Yield data were gathered annually during the coffee-picking season (October-January). Every 15 days picking was done by hand during approximately 4 months. After the picking season, the experimental area was cleaned by hand of all weeds and the shade trees were pruned to leave less than 50-percent shade. The fertilizer treatments were applied to the plots immediately after the end of the picking season. From there on, they were weeded once or twice during the rest of the year.

TABLE 2.-Combined mean yield for 2 cofee cultivars in a Los Guineos clay

\begin{tabular}{|c|c|c|c|c|}
\hline \multicolumn{3}{|c|}{ Description of treatments ${ }^{1}$} & \multicolumn{2}{|c|}{ Mean yicld 2} \\
\hline $\mathrm{N}$ & $\mathrm{P}=\mathrm{Os}$ & $\mathrm{K}, \mathrm{O}$ & $\begin{array}{l}\text { Puerto Rico, } \\
8 \times 8 \mathrm{ft.}^{3}\end{array}$ & $\begin{array}{l}\text { Columnaris, } \\
12 \times 12 \mathrm{ft} \text {. }\end{array}$ \\
\hline Lb./acre & Lb./acre & Lb./acre & Cwwl./acre/yr. & Cat./acre/yr. \\
\hline 0 & 300 & 300 & $8.66 \mathrm{~b}^{3}$ & $6.04 \mathrm{a}$ \\
\hline 100 & 300 & 300 & $13.19 \mathrm{a}$ & $6.06 \mathrm{a}$ \\
\hline 200 & 300 & 300 & $13.53 \mathrm{a}$ & $6.14 \mathrm{a}$ \\
\hline 300 & 0 & 300 & $12.66 \mathrm{a}$ & $5.95 \mathrm{a}$ \\
\hline 300 & 100 & 300 & $12.28 \mathrm{a}$ & $6.07 \mathrm{a}$ \\
\hline 300 & 200 & 300 & $13.36 a$ & $6.10 \mathrm{a}$ \\
\hline 300 & 300 & 0 & $7.65 \mathrm{~b}$ & $6.19 \mathrm{a}$ \\
\hline 300 & 300 & 100 & $7.64 \mathrm{~b}$ & $6.11 \mathrm{a}$ \\
\hline 300 & 300 & 200 & $13.46 \mathrm{a}$ & $6.19 \mathrm{a}$ \\
\hline 300 & 300 & 300 & $13.82 \mathrm{a}$ & $0.13 \mathrm{a}$ \\
\hline 0 & 0 & 0 & $7.30 \mathrm{~b}$ & $6.17 \mathrm{a}$ \\
\hline 300 & 300 & 300 & $13.24 \mathrm{a}$ & $6.13 \mathrm{a}$ \\
\hline
\end{tabular}

1 All treatments except the last 2 received an original lime application to raise soil pH to 6.5 .

2 Mean yield for 6 and 5 replications for the Puerto Rico and Columnaris cultivars, respectively.

${ }^{3}$ Treatments with the same letter or set of letters do not differ at the 5-percent level of significance.

The combined 6-year data were analyzed through analysis of variance, and a regression curve was fitted to the results to determine the overall effect of each major nutrient on yield.

Leaf samples from the fourth leaf starting from the tip were gathered during the years 1962-63 at different time intervals. The samples were chemically analyzed for nitrogen, phosphorus and potash depending on the element that was varied in the treatment.

\section{RESULTS AND DISCUSSION}

The results for the Puerto Rico and Columnaris coffee cultivars are presented in tables 1 and 2 . Table 1 shows the annual mean yield of market 
coffee per acre for six consecutive crops of the Puerto Rico cultivar, while table 2 shows the combined mean yields for each cultivar.

A definite tendency to increase the yield irrespective of nutrient during the first three crop-means was clearly observed. In the second, fourth, ninth, and twelfth treatments the increase in yield was extended to the fourth crop (table 1). Thereafter the annual production tended to follow a definite cycle either of 1 or 2 years. Definitely, the biennial bearing habits were not overcome by the nutrient applications. The results with the Columnaris cultivar are not presented because the data followed the same general tendency with minor variation in yields.

The overall effect of the major nutrients and lime are presented in table 2 and figure 1. The analysis of variance for the Columnaris cultivar showed no significant differences among treatments. The data corroborated previous results reported by Rodriguez, et al. (10). Theoretically, an annual production of 6 hundredweights of market coffee will remove approximately 18 pounds of $N, 9$ pounds of $P$, and 11.4 pounds of $K$ from a soil. The previous values were based on analytical data for Bourbon coffee grown at the Coffee Substation (9) which are higher for nitrogen than the values presented by workers in Brazil, but not so for potassium and phosphorus (3). Since the Columnaris cultivar is a vigorous tree, there is the possibility of having enough nutrient supply from the soil because of a better root system and the decomposition of organic matter or any other possible source of nutrients including rainwater.

The analysis of variance for the Puerto Rico coffee showed a definite response to the treatment differentials. The omission of nitrogen, potash, or all three major elements (check) brought a decrease in yield. The omission of phosphorus or lime did not affect significally the mean yield. The previous fact had been observed for the same two coffee cultivars by Rodríguez, et $a l$. in Alonso and Catalina clays (10).

A second-degree equation was fitted to the results to obtain the overall effect of each major nutrient on yield (fig. 1). Although none of the curves was statistically significant, some observations can be made about them. The increase in nitrogen application up to approximately 250 pounds brought about an increase in yield, beyond which application there is a tendency to decrease. Phosphorus did not markedly affect the yield, while potassium produced a definite increase in yield. The increase in yield owing to potassium may go further than 300 pounds per acre per year. It is somewhat curious that the first increment of potassium did not increase yield as was expected. The possible explanation must be based on the fixing capacity of the soil, so that the first 100 pounds did serve to satisfy it, or to an unbalanced condition of the nutrients in the soil. If the levels of nutrients should have been increased beyond the 300 pounds, possibly the curve best 

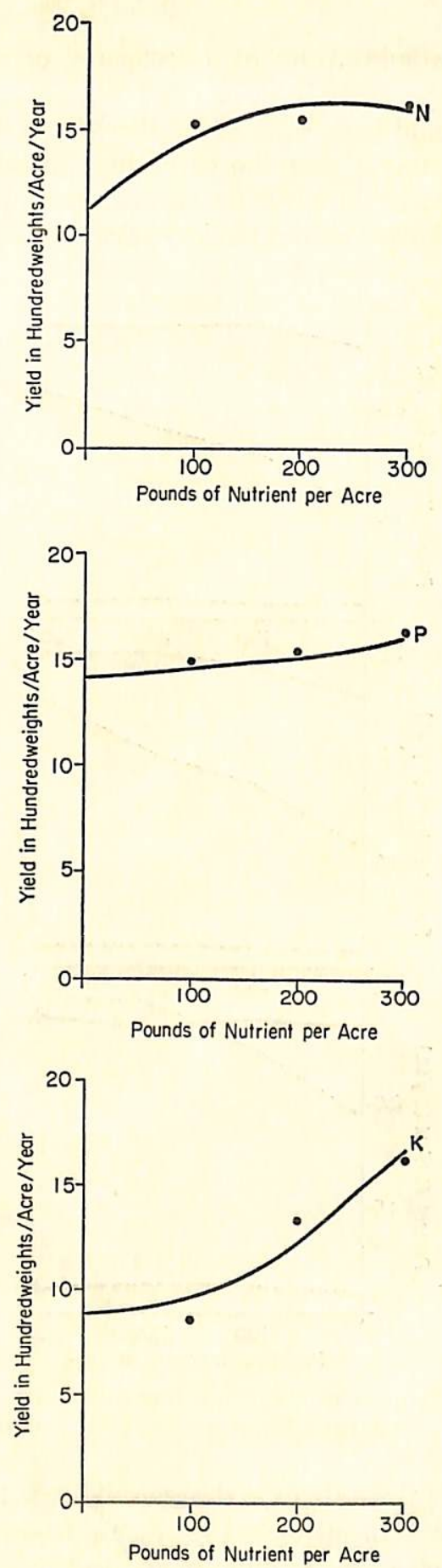

FIg. 1.-Regression curves obtained by fitting a second-degree equation to the yields obtained by applying different levels of major nutrients to Puerto Rico coffee cultivar. 
fitting the results would have been of another shape. Capó, working with sugarcane and corn, found that the curve best fitting the results had a bell-shape very similar to the curve for normal distribution (5). In our case the observed values for potassium tend to have the previous shape.



Fig. 2.-Effect of different levels of major nutrients on the chemical composition of coffee leaves for samples gathered in April, October, and March.

Leaf analyses made three times in the year did not show too much variation in phosphorus and in nitrogen (fig. 2). Leaf potassium definitely increased with the levels of potassium applied to the soils. In fact, time of sampling showed some variation, being higher in March than in April and 
October. In general, the values obtained were close to those reported by other workers in the coffee literature for similar conditions as summarized by Rodriguez (9).

The leaf-nutrient data were transformed to the arc-tan-percent $\mathrm{Nu}$. The

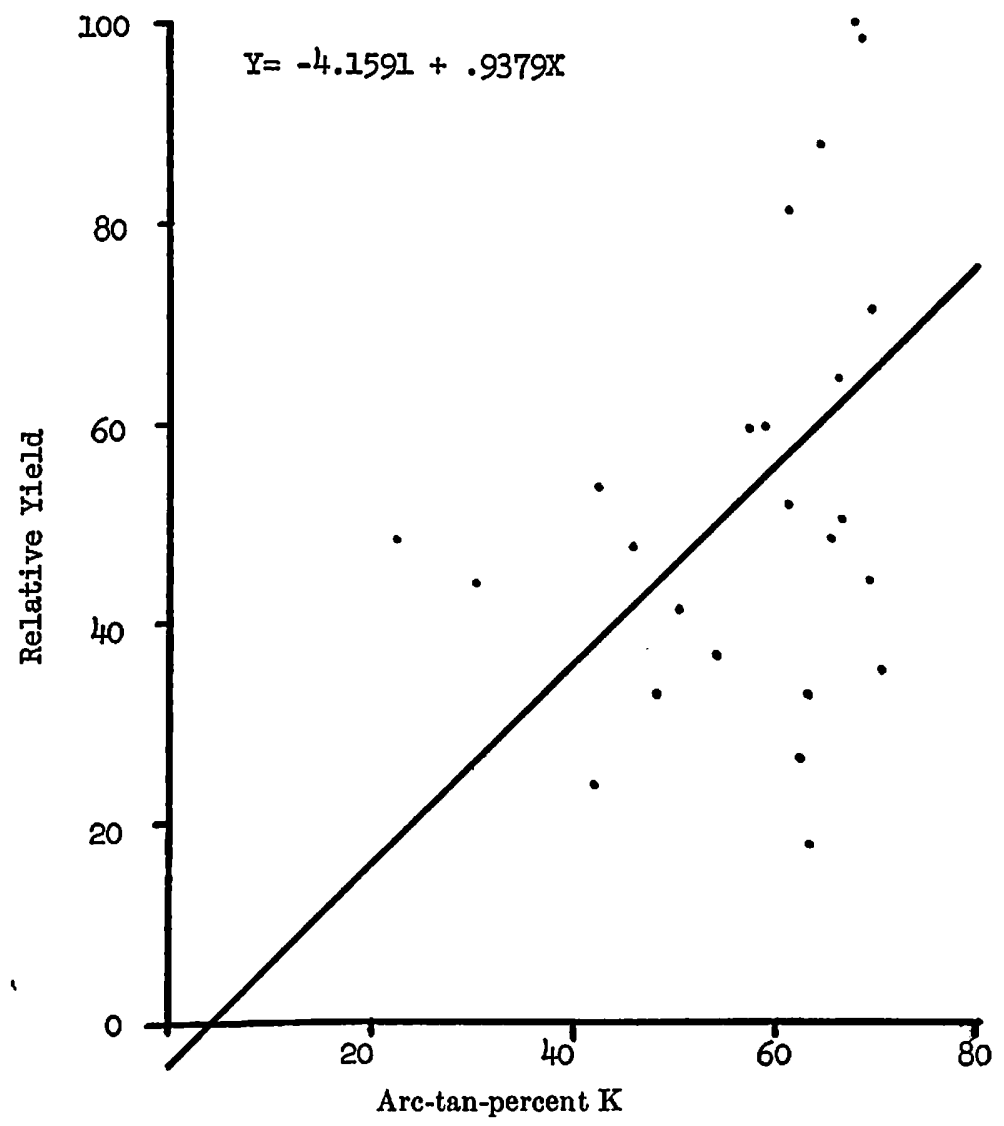

FIG. 3.-Yield-nutrient relationship obtained by transforming the content of leaf potassium through Capó's equation $Y=\operatorname{arc-tan-percent~} K$ of the October sample and the subsequent crop.

transformed data were correlated with the next two consecutive crops applying the equation $Y=A+B$ arc-tan $X$ as recommended by Capó and Samuels $(6)$ in which $X$ is the percentage of leaf nutrient. The only significant positive correlation was obtained with leaf potassium of the October sample with the subsequent crop (fig. 3). The relative yield was based on the highest producing plot of all those receiving potassium in the differential treatments. 
The possible explanation for that positive significant correlation is based on the fact that, during the period of sampling, the trees are maturing a crop, and at the same time new growth is being developed for the subsequent crop. During that time the requirements for nutrients are at their maximum as has been pointed out by other workers.

\section{SUMMARY}

Two experiments were run on coffee in a Los Guineos clay near Jayuya. The Columnaris and Puerto Rico cultivars were differentially treated with levels of major nutrients and lime to observe the results in yield and leafnutrient levels. No differences in yield were obtained with the Columnaris, but significant differences were obtained with the Puerto Rico cultivar The omission of nitrogen or potassium and all major nutrients together. (check) reduced the yields. Lime did not affect the yield in the presence of all the major nutrients.

The overall effect of three major nutrients, as judged by regression analysis of the yield curve against level of nutrients applied fitting a seconddegree equation, was not significant.

Leaf samples gathered during three different periods did not show too much variation in nitrogen and phosphorus. Potassium showed a definite trend to increase with increased levels of the nutrient when applied to the soil and to vary with the time of sampling. The transformed data using Capo's equation $Y=A+B$ arc-tan $X$ in which $X$ was the percentage of leaf nutrient proved to be significantly correlated with yield only with leaf potassium of samples taken in October and the yield of the incoming crop.

\section{RESUMEN}

Se trataron dos tipos de café con diversos niveles de elementos mayores y cal en un suelo Los Guineos arcilloso en Jayuya, sin que se afectara el rendimiento en el tipo Columnaris pero sí en el tipo Puerto Rico. Al excluirse el nitrogeno y el potasio se redujo el rendimiento de los arbustos. Lo mismo ocurrió cuando a manera de testigo se excluyeron todos los elementos mayores (nitrógeno, fósforo y potasio). La aplicación de cal no afectó los rendimientos cuando los demás elementos mayores estaban presentes.

Las curvas de regresión, aplicando una ecuación de segundo grado a los resultados, demostraron que ninguno de los elementos afectó significativamente los rendimientos, debido posiblemente a los pocos puntos de distribución en las curvas.

Las muestras foliares tomadas en tres épocas distintas del año no demostraron mucha variación en el contenido de nitrógeno y fósforo. El potasio reveló una tendencia a aumentar con un aumento en los niveles del nutri- 
mento aplicado al suelo, a la vez que a variar según la época en que se tomaron las muestras. Al aplicarse a las tres muestras la ecuación de Capó $Y=A+B$ arc-tan $X$, en donde $X$ es igual al por ciento de nutrimento en la hoja, los datos transformados demostraron estar significativamente correlacionados con el rendimiento, únicamente en el caso del potasio, en las muestras foliares tomadas en octubre y la cosecha subsiguiente.

\section{LITERATURE CITED}

1. Abruña, Fernando, Vicente-Chandler, José, and Silva, Servando, The effect of different fertility levels on yields of intensively managed coffee in Puerto Rico; J. Agr. Univ. P.R. 48 (3): 141-6, 1959.

2. Abruña, Fernando, Vicente-Chandler, Jose, Becerra, Luis A., and Bosque-Lugo, Ramón, Effects of liming and fertilization on yields and foliar composition of high-yielding sungrown coffee in Puerto Rico; J. Agr. Univ. P.R. 49 (4): 413$28,1965$.

3. Arzolla, S., Gómez, L., Sarriage, J. R., Andrade, R. G., Graner, E. A., and Malavolta, E., Estudios sobre la nutrición mineral del cafeto, X. Extracción de elementos nutritivos mayores, macroelementos en la recolección de variedades "Mundo Novo", "Caturaa" y "Bourbon Amarelo", Revista de la Potasa, Instituto Nacional de la Potasa, Berna, Suiza, 10 pp. Oct. 1965.

4. Bonnet, J. A., Riera, A. R., and Lugo-López, M. A., Lack of response of old coffee trees grown in Alonso clay to lime and phosphatic fertilization, $J$. Agr. Univ. P.R. 48 (3): 161-6, 1958.

5. Capó, B. G., Personal communication.

6. Capó, B. G., and Samuels, G., The development of a mathematical concept to interpret the relation between plant composition and crop yield, J. Agr. Univ. P.R. 87 (4): 249-64, 1953.

7. Gómez, L. A., Lería-Esmoris, J., and Capó, B. G., Fertilizer requirements for coffee grown in a Catalina clay in Puerto Rico, J. Agr. Univ. P.R. $\$ 0$ (3): 127$37,1946$.

8. McClelland, T. B., Experiments with fertilizers for coffee in Puerto Rico, Fed. Agric. Exp. Sta. (Mayagüez) Bull. 31, 34 pp., 1926.

9. Rodriquez, Saulo J., The chemical composition of green coffee beans and coffee leaves as related to soil and foliar applications of secondary and minor elements; Thesis submitted for the degree of Doctor of Philosophy to Michigan State University, Department of Horticulture, 100 pp., 1961.

10. Rodríguez, Saulo, J., Bosque-Lugo, R., Pérez-Pérez, R., and Rodríguez Cabrera, A., Yield response of the Puerto Rico and Columnaris coffee cultivars in two latosols of Puerto Rico as affected by different levels of nitrogen, phosphorus, potassium and lime, J. Agr. Univ. P.R. 48 (3): 255-62, 1964. 